\title{
PEMBERDAYAAN PESANTREN MIFTAHUL ULUM MELALUI BUDIDAYA SAYURAN SECARA ORGANIK DENGAN TEKNOLOGI TAKAKURA
}

\author{
Jaini Fakhrudin"1), Danie Indra Yama1), Mujib(2) Muhammad Ridwan') Robiatun Nisa') \\ 1)Jurusan Teknologi Pertanian, Politeknik Negeri Pontianak, Pontianak, Kalimantan Barat, Indonesia \\ 2)Jurusan Teknik Mesin, Politeknik Negeri Pontianak, Pontianank, Kalimantan Barat, Indonesia \\ Corresponding author : Jaini Fakhrudin \\ E-mail : jai_fakh@yahoo.com
}

\section{Diterima 30 Oktober 2020, Direvisi 15 November 2020, Disetujui 15 November 2020}

\begin{abstract}
ABSTRAK
Yayasan Ponpes Miftahul Ulum yang berada di Desa Ambangah memiliki lahan seluas 10 ha yang belum terkelola dan dimanfaatkan. Pengelolaan lahan tersebut masih terkendala karena sumberdaya dan keuangan. Praktek bercocok tanam saat ini hanya untuk kegiatan pembelajaran siswa pada mata pelajaran Muatan Lokal. Kemampuan manajerial usaha juga masih rendah dan tidak ada pembukuan yang jelas. Tujuan pelaksanaan kegiatan ini adalah supaya pihak pesantren memahami Teknik budidaya sayuran organik dengan teknologi takakura. Kegiatan pemberdayaan pesantren melalui pertanian organik takakura akan menjadi sarana pembelajaran yang efektif dan menjadi nilai tambah serta meningkatkan kemampuan usaha dan ekonomi ponpes khususnya para siswa. Selain itu kegiatan pertanian di pesantren akan menambah variasi kegiatan dan aktivitas baru yang produktif serta menjadi percontohan bagi masyarakat sekitar. Para siswa dan stakeholders terkait juga diajarkan pembuatan pupuk organik sistem takakura, budidaya tanaman sayuran yang sesuai rekomendasi, diajarkan kemampuan pengelolan Lembaga dan keuangan serta pemasaran produk. Metode pelaksanaan kegiatan yaitu melalui penyuluhan, pelatihan dan pendampingan kepada mitra serta praktik langsung dilapangan. Evaluasi kegiatan dilaksanakan secara berkala untuk memantau pelaksanaan dan tindak lanjut kegiatan di lapangan dengan cara survey langsung ke lokasi mitra dan pemberian kuesioner. Adapun capaian yang sudah dilaksanakan yaitu meningkatan pengetahuan dan keterampilan sumberdaya manusia dalam pembuatan kompos takakura, budidaya tanaman sayuran organik dengan metode yang efektif yaitu sistem takakura dan pemanfaatan lahan tidur yang dimiliki pondok pesantren untuk budidaya empat jenis sayuran.
\end{abstract}

Kata kunci: pemberdayaan; pertanian organik; takakura.

\begin{abstract}
The Foundation of Miftahul Ulum Ponpes, which is located in Ambangah Village, has a land area of 10 hectares that has not been managed and utilized. The land management is still constrained due to resources and finance. The current farming practice is only for student learning activities in Local Content subjects. Business managerial ability is still low and there is no clear accountancy. The purpose of implementing this activity is so that the partners understand the organic vegetable faarming technique using takakura technology. The activities of empowering the boarding school through takakura organic farming will be an effective means of learning and become an added value as well as increase the business and economic capacity of the boarding school, especially students. In addition, agricultural activities at the boarding school will add variety to new productive activities and activities as well as become a model for the surrounding community. The students and related stakeholders were also taught how to make organic fertilizer for the takakura system, cultivate vegetables according to recommendations, teach the ability of institutional management and finance and product marketing. The method of implementing activities is through counseling, training and mentoring to partners and direct practice in the field. Evaluation of activities is carried out regularly to monitor the implementation and follow-up of activities in the field by means of direct surveys to partner locations and giving questionnaires. The training is carried out to coach any partners and direct practice in the field. The training has been increasing the knowledge and skills of human resources in making takakura compost, cultivating organic vegetable with effective methods, namely the takakura system and the use of land owned by the boarding school for the cultivation of several types of vegetables.
\end{abstract}

Keywords: empowerment; organic farming; takakura. 


\section{PENDAHULUAN}

Pondok Pesantren Miftahul Ulum terletak di Desa Sungai Ambangah yang meiliki jarak tempuh dari kampus Politeknik Negeri Pontianak $\pm 24 \mathrm{Km}$. Desa Sungai Ambangah secara geografis memiliki luas wilayah 16.560 Ha. yang terdiri dari 5 dusun. Adapun fasilitas pendidikan yang terdapat di Desa Sungai Ambangah antara lain: 3 buah PAUD, 5 buah SD, 2 Buah SMP dan 2 buah SMA. Dari sejumlah fasilitas pendidikan tersebut beberapa diantaranya berada di bawah yayasan Pondok Pesantren Miftahul Ulum.

Apabila dilihat dari lokasinya Desa Sungah Ambangah adalah sebuah Desa yang masuk dalam katagori Desa Tertinggal dari sosial kependidikan, tertinggal dari sosial Ekonomi dan tertinggal dari perhatian pemerintah dan perhatian tokoh Agama. Sebagai pemukiman tertinggal sering terjadi berbagai permasalahan terutama permasalahan Ekonomi, termasuk Dekadensi moral dan kemiskinan, tempat tersebut banyak menjadi tempat berjudi, menyabung ayam dan perampokan, serta menjadi persembunyian pelaku kejahatan.

Dibutuhkan usaha lebih keras lagi agar Pondok Pesantren Miftahul Ulum dapat memberikan dampak yang lebih besar kepada masyarakat Desa Sungai Ambangah, salah satunya dengan memanfaatkan lahan yang dimiliki oleh Yayasan seluas 10 ha yang masih belum dimanfaatkan secara optimal. Sampai sekarang lahan tersebut belum digarap dan dimanfaatkan secara optimal oleh Yayasan sementara jika dikelola dengan baik akan berdampak terhadap peningkatan keekonomian para santri. Kemampuan ekonomi para santri umumnya menengah ke bawah, sehingga perlu adanya pemberdayaan dan perhatian oleh beberapa pihak melalui kerja sama dengan pihak Yayasan. Jumlah santri saat ini berjumlah sebanyak 354 orang.

Kegiatan praktikum bercocok tanam sayuran oleh para santri di sekitar Ponpes namun dibutuhkan pembinaan agar pemanfaatan lahan untuk bercocok tanam sayuran bisa lebih optimal dan memberikan dampak yang signifikan tidak hanya untuk pondok pesantren serta masyarakat desa sungai ambangah secara umum. Permasalahan mitra di atas harus segera mendapatkan solusi. Adapun permasalahan yang dialami oleh mitra secara lebih rinci adalah sebagai berikut: mitra belum memiliki pengetahuan dan keterampilan serta keahlian dalam bercocok tanam sayuran dengan metode yang efektif yakni Budidaya Sayuran Secara Organik dengan Teknologi Takakura, mitra mempunyai keterbatasan kemampuan untuk memberdayakan para siswa yang punya keterbatasan ekonomi dan rendahnya pendidikan para orang tua siswa, mitra belum memiliki pengetahuan dan keterampilan terapan pada bidang manajemen usaha, mitra belum memiliki pengetahuan dan keterampilan terapan pada bidang pemasaran produk. Tujuan Kegiatan adalah supaya mitra memahami Teknik budidaya sayuran organik dengan teknologi pengomposan Takakura.

\section{METODE PELAKSANAAN Mitra Kegiatan}

Mitra kegiatan ini adalah Pesantren Miftahul Ulum, Kabupaten Kuburaya, Kalimantan Barat. Target kegiatan yaitu para siswa, para guru, dan pihak manajemen sekolah. Pelatihan pengomposan Takakura melibatkan peserta sebanyak 40 orang, sementara pihak manajemen sekolah yang terlibat dalam Focus Group Discussion (FGD) sebanyak 5 orang.

\section{Teknologi Pengomposan Takakura}

1. Penyuluhan Teknik Pengomposan metode Takakura

Penyuluhan dilakukan dengan metode presentasi dengan menjelaskan definisi, cara kerja, manfaat metode pengomposan Takakura dan mendemonstrasikan cara kerja pengomposan metode Takakura dan aplikasinya

2. Pembuatan Kompos dengan Metode Takakura

Persiapan Alat dan Bahan

Alat yang digunakan adalah keranjang $50 \mathrm{~L}$ beserta tutupnya, gunting, cangkul, jarum jahit dan benang. Bahan yang digunakan adalah kardus, sekam kering, kain jaring, EM4, air cucian beras, tetes tebu/gula pasir, kain strimin, kotoran sapi, kompos, dan tali.

Pembuatan Kompos Metode Takakura

Menurut (Widikusyanto, 2018), tahapan pembuatan kompos metode Takakura sebagai berikut:

a. Menyiapkan keranjang yang berlubang-lubang kecil agar proses aerob dapat berlangsung dengan baik

b. Menyusun keranjang pada tempat yang teduh dan tidak terkena hujan, sinar matahari langsung serta sirkulasi udara sekitar yang bagus

c. Membuat bantal dengan cara kain jaring dibuat seperti kantong dengan ukuran sesuai ukuran keranjang dan mengisinya dengan sekam kering hingga penuh kemudian dijahit hingga menyerupai bantal

d. Menyemprot kotoran sapi dengan EM4 $300 \mathrm{ml} / 10 \mathrm{~kg}$ yang telah dicampur air 
cucian beras dan tetes tebu/gula pasir 15 gram dengan perbandingan (1:5) dan diaduk hingga merata (Manuputty, Jacob, \& Johanis P, 2018).

e. Memasukkan bahan kedalam keranjang dengan susunan seperti Gambar 1. Adapun susunan nya adalah sebagai berikut :

- Melapisi keranjang bagian dalam menggunakan kardus dan diikat menggunakan tali, yang berfungsi menghindari gangguan dari serangga, mengatur kelembaban dan

- menyerap udara dan air

- Meletakkan bantal sekam pada dasar keranjang, bantal tersebut berguna agar perkembangan mikroba berkembang dengan baik sehingga mempercepat pembusukan, selain itu juga berfungsi menyerap air, mengurangi bau dan mengontrol kelembaban.

- Memasukkan kompos yang sudah jadi dengan ketinggian $5 \mathrm{~cm}$ yang berfungsi sebagai activator pada proses pengomposan

- Memasukkan kotoran sapi yang telah disemprot EM4 kedalam keranjang

- Memasukkan bantal sekam, tutup mulut keranjang menggunakan kain strimin dan tutup keranjang rapat agar serangga tidak dapat masuk

f. Melakukan perawatan hingga kompos matang dengan ciri teksturnya seperti tanah, warna coklat kehitaman dan tidak berbau), proses pengomposan terjadi selama 10 hari (Nurullita \& Budiyono, 2012). Kegiatan perawatan meliputi pengontrolan kompos dilakukan seminggu sekali dengan mengontrol kelembaban kompos dan Suhu. Jika udara sekitar tidak terasa hangat maka percikkan sedikit air. Kadar air optimum untuk pengomposan bahan dasar daun kering dengan model Takakura adalah 60\% (Ratna, Sumiyati, \& Samudro, 2017). Berdasarkan SNI 19-7030-2004 suhu standar pengomposan yaitu suhu air tanah dengan $\mathrm{pH}$ minimal 6,80 dan maksimal 7,49. Desain metode pengomposan Takakura menurut (Ratna et al., 2017).

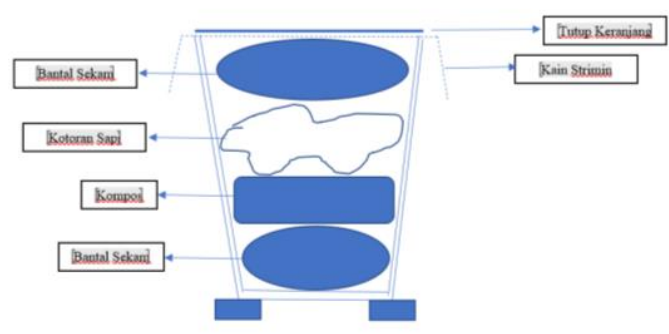

Gambar 1. Metode Takakura

Panen Kompos

Mengeluarkan kompos dari keranjang, kemudian memisahkan kompos gelap dan diayak. Mematangkan kompos selama satu minggu dengan cara diangin-anginkan di tempat yang tidak terkena sinar matahari secara langsung.

\section{Aplikasi kompos pada Tanaman Sayuran}

Alat yang digunakan adalah cangkul, pot tray penyemaian, tugal, mal jarak tanam. Bahan yang digunakan yaitu paranet, dolomit, pupuk kandang, benih sayuran, fungisida, mulsa, jerami kering,

Persiapan lahan diawali dengan membersihkan gulma secara manual dengan cara dibabat menggunakan parang dan cangkul. Setelah itu dilakukan pengolahan tanah dengan mencangkul hingga kedalaman kurang lebih 20-30 cm, membolak balikkan dan meratakan tanah menggunakan cangkul. Kemudian menambahkan pupuk kandang sebanyak 20 ton/ha dan dolomit sebanyak $600 \mathrm{~kg} / \mathrm{ha}$ (Sudaryono, Wijanarko, \& Suyamto, 2015) dicampur dan diratakan kembali. Selanjutnya dibuat bedengan dengan arah membujur dari Timur ke Barat dengan lebar $100 \mathrm{~cm}$ dan tingginya $30 \mathrm{~cm}$ dan ditutup dengan mulsa hitam perak yang sudah diberi lubang sesuai dengan jarak tanam. Sebelum penanaman, dilakukan inkubasi selama 1 minggu.

Persiapan bibit dilakukan dengan persemaian benih sayuran menggunakan pot tray semai sayuran. Persemaian dilakukan pada tempat terbuka yang dipasang naungan menggunakan paranet. Persemaian dilakukan dengan menyeleksi benih menggunakan air bersih. Benih yang terapung dibuang dan benih yang tenggelam direndam kedalam larutan fungisida dengan konsentrasi $0,1 \%$ lebih selama 2 jam dan tiriskan. Setelah itu isi pot tray dengan tanah dan tanam benih kedalamnya serta menyiramnya hingga kapasitas lapang, kemudian ditutup dengan alang-alang atau jerami kering selama 2-3 hari. Setelah berumur 7 hari atau sudah terbentuk organ tanaman sempurna kurang lebih 4-5 helai daun maka dilakukan pindah tanam ke bedengan yang sudah dipersiapkan. 
Kegiatan penanaman dilakukan dengan membuat lubang tanam dengan tugal dan dibuat jarak tanam $20 \mathrm{~cm} \times 20 \mathrm{~cm}$. Dalam satu lubang tanam diisi dengan satu bibit dari persemaian.

Pemeliharaan meliputi penyiraman, penyulaman untuk tanaman yang mati, pengendalian hama, penyakit, gulma secara mekanik dan setelah itu dua minggu setelah tanam dilakukan pemupukan dengan cara menabur kompos dalam barisan atau melingkari tanaman sebanyak 75 gram/tanaman (Safei, Rahmi, \& Jannah, 2014).

Sayuran dapat dipanen setelah umur 12 bulan. Tanaman yang baru dipanen, ditempatkan di tempat yang teduh agar tidak cepat layu. Dilakukan sortasi untuk memisahkan bagian tanaman tua, busuk atau sakit. Penyimpanan menggunakan wadah keranjang bambu, wadah plastik atau karton yang berlubang-lubang untuk menjaga sirkulasi udara.

\section{Partisipasi Mitra dalam Pelaksanaan Program}

Partisipasi mitra yang dilakukan yaitu menyediakan tempat dan sumber daya manusia untuk dilatih, melaksanakan, memonitoring serta mengevaluasi atas capaian program yang dilaksanakan, sedangkan tim pelaksana PKM dari perguruan tinggi memfasilitasi dan mendampingi serta membina mulai dari perencanaan hingga akhir program. Tim pelaksana dapat menyalurkan ilmu pengetahuan dan teknologi serta memotivasi dalam peningkatan keterampilan dalam bidang pertanian.

\section{Evaluasi Pelaksanaan Program}

Kegiatan evaluasi dilakukan guna mengetahui seberapa besar tingkat keberhasilan atau kegagalan terhadap kondisi permasalahan yang ada pada mitra. Kegiatan ini dilaksankan antara tim PKM terhadap mitra. Evaluasi dilakukan mulai dari kegiatan penyuluhan sehingga dapat diketahui sejauh mana pengetahuan mitra dalam teknologi pengomposan takakura dan budidaya sayuran organic sehingga tim PKM mengetahui sejauh mana tujuan dari program yang dapat dicapai, Kemudian evaluasi dilakukan secara berkala setelah pelaksanaan pelatihan untuk mengetahui perkembangan kegiatan dalam pengaplikasian pembuatan kompos takakura dan budidaya sayur secara organik. Setelah panen, dilakukan evaluasi terhadap keberlanjutan program pada masyarakat dalam mengaplikasikan teknologi tersebut dalam kehidupan sehari-hari.

\section{Focus Group Discussion (FGD) dan Pelatihan Pemasaran}

Focus Group Discussion (FGD) biasa juga disebut sebagai metode dan teknik pengumpulan data kualitatif dengan cara melakukan wawancara kelompok. Dalam FGD, sekelompok orang berdiskusi tentang suatu fokus masalah atau topik tertentu dipandu oleh seorang fasilitator atau moderator. FGD merupakan metode dan teknik pengumpulan data atau informasi yang awalnya dikembangkan di dalam penelitian pemasaran, yakni digunakan untuk mengetahui citra tentang produk tertentu, hal-hal apa yang menarik calon pembeli atau konsumen, disain produk, pilihan ukuran, pilihan warna, disain kemasan, hal-hal apa yang perlu diperbaiki dan sebagainya. Dalam perkembangannya kemudian pemakaian FGD dengan cepat meluas pemanfaatannya di dalam ilmu-ilmu sosial

Manfaat yang diperoleh dari FGD adalah bahwa dalam waktu relatif singkat (cepat) dapat digali mengenai persepsi, pendapat, sikap, motivasi, pengetahuan, masalah dan harapan perubahan berkaitan dengan masalah tertentu

\section{HASIL DAN PEMBAHASAN \\ Pelaksanaan Teknologi Pengomposan Takakura}

Bercocok tanam merupakan kegiatan yang pernah dilakukan di Pondok Pesantren Miftahul Ulum namun, informasi teknologi pembuatan kompos dan budidaya tanaman sayuran belum diketahui oleh warga Pondok Pesantren tersebut. Hasil survey pendahuluan bahwa selama ini kegiatan budidaya tanaman yang dilakukan masih menggunakan teknologi secara turun menurun, pengolahan limbah kandang maupun dapur masih belum termanfaatkan, sebagian besar masih menggunakan pupuk kimia, masih banyak yang belum mengetahui teknologi pengolahan limbah menjadi pupuk. Budidaya tanaman sayuran dengan metode takakura ini dikenalkan kepada pondok pesantren Miftahul Ulum dengan metode pelatihan baik pemberian materi pembuatan kompos dan praktik langsung serta dilakukan pendampingan terhadap budidaya tanaman sayuran. Antusiasme siswa dalam mengikuti program ini sangat tinggi, mereka merasa bahwa menghasilkan pangan sehat berawal dari petani sendiri. Setelah dilakukan pelatihan dan pendampingan pembuatan kompos takakura dan budidaya tanaman sayuran maka pengetahuan dan keterampilan mitra meningkat. Berikut merupakan hasil survey yang dilakukan setelah dilakukan pelatihan dan pendampingan. 


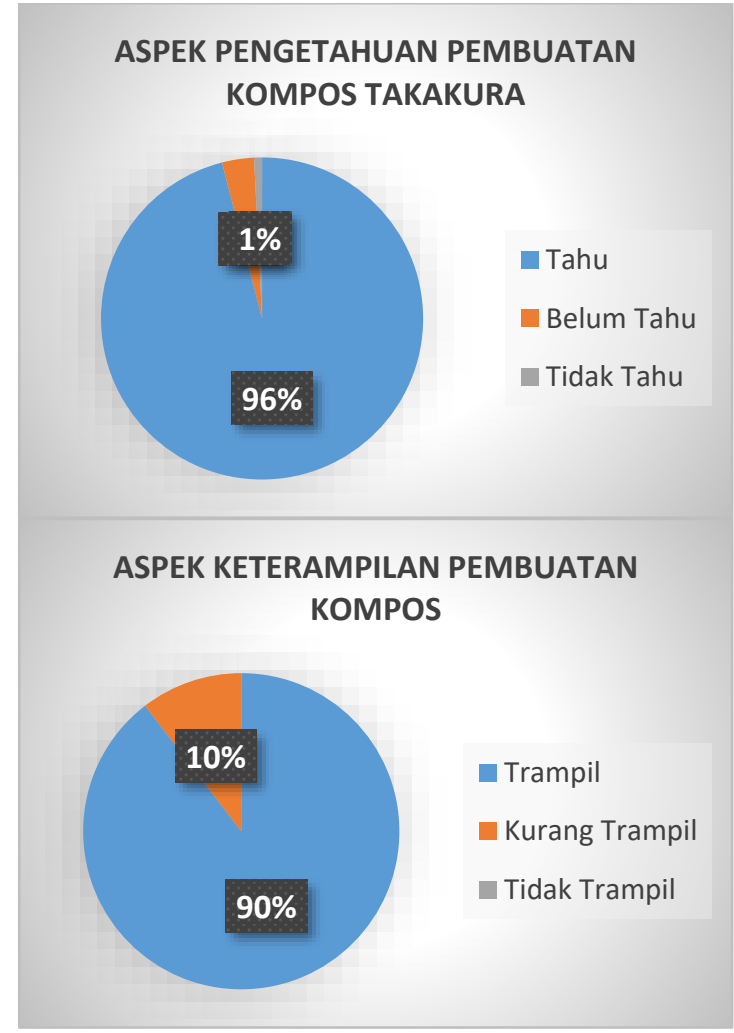

Gambar 2. Hasil Survei Aspek Pengetahuan dan Keterampilan Kegiatan Pembuatan Kompos

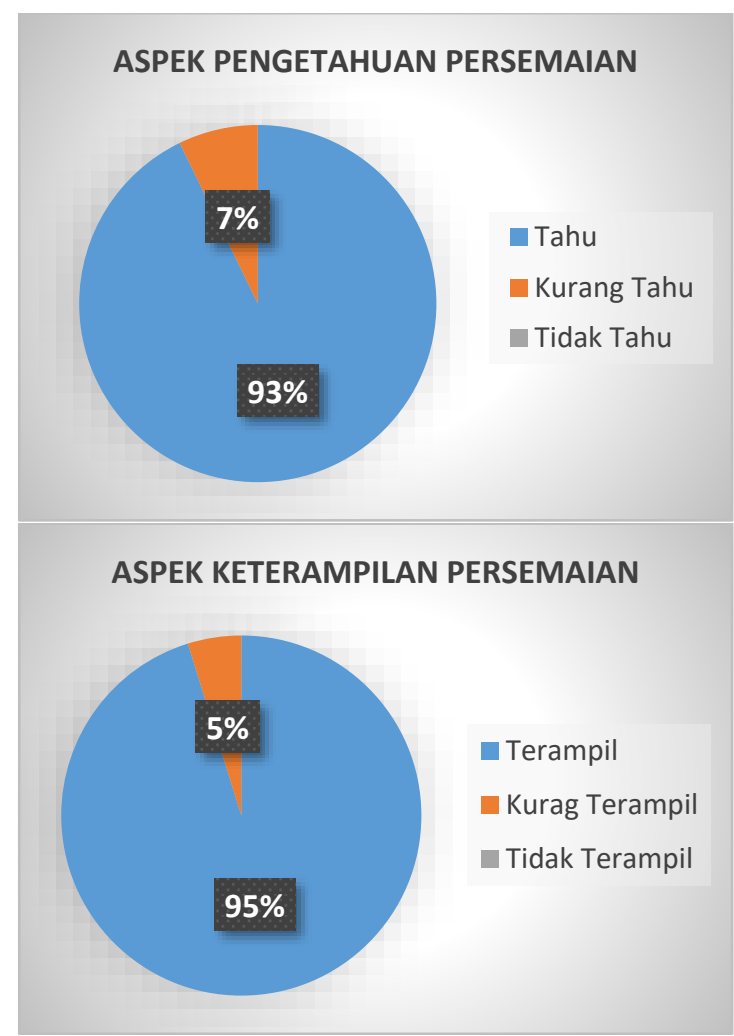

Gambar 3. Hasil Survei Aspek Pengetahuan dan Keterampilan Kegiatan Persemaian

\section{ASPEK PENGETAHUAN PENGOLAHAN} LAHAN

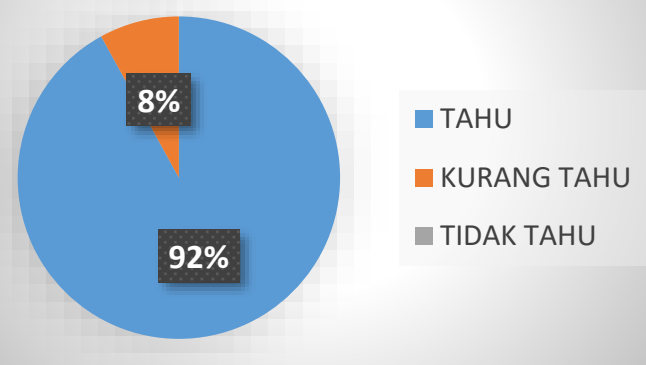

ASPEK KETERAMPILAN PENGOLAHAN LAHAN

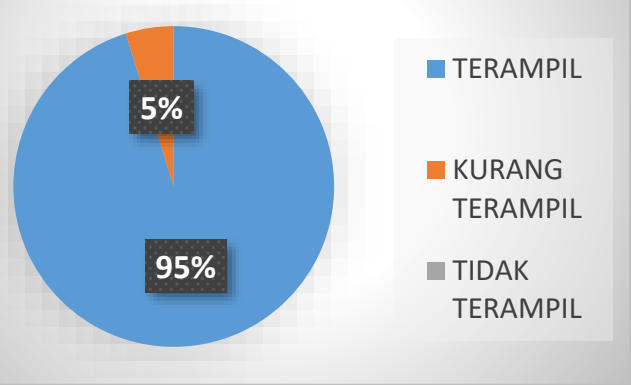

Gambar 4. Hasil Survei Aspek Pengetahuan dan Keterampilan Kegiatan Pengolahan Lahan

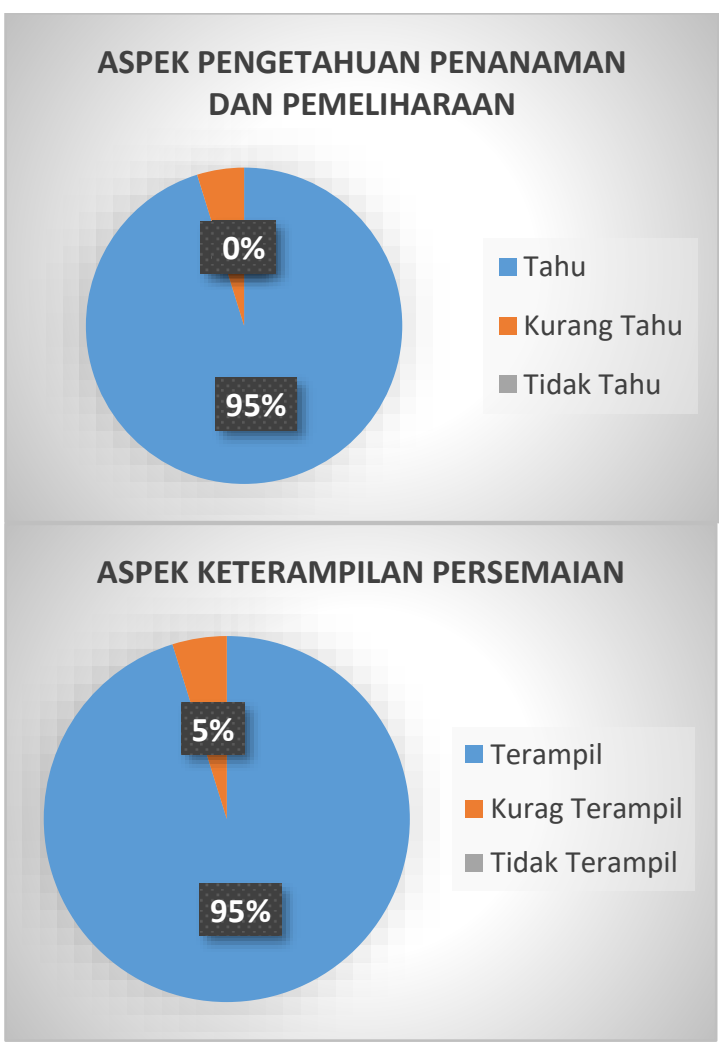

Gambar 5. Hasil Survei Aspek Pengetahuan dan Keterampilan Kegiatan Penanaman dan Pemeliharaan 
Berdasarkan hasil survey seperti ditunjukkan pada Gambar 5. pengetahuan dan keterampilan siswa pada budidaya sayuran organik dengan sistem takakura dinilai berdasarkan jawaban hasil survey. Gambar diatas merupakan hasil dari survey baik dari dari aspek pengetahuan dan keterampilan mitra setelah dilakukan pelatihan dan pendampingan. Ketercapaikan tujuan pelatihan pembuatan kompos dan teknik budidaya tanaman sayuran dapat dikatakan baik (>90\%), target materi yang direncanakan dan semua materi yang disampaikan dari pembuatan kompos hingga budidaya tanaman secara teori diruangan maupun praktik langsung oleh tim pengabdian juga tergolong baik, dan kemampuan peserta dalam penguasaan materi dapat dikatakan baik.

Dari hasil survey seperti pada Gambar 2. menunjukkan aspek pengetahuan menghasilkan skor persentase 96\% tahu terhadap materi pembuatan pupuk kompos takakura dan $90 \%$ terampil dalam pembuatan kompos takakura. Keterampilan dan pengetahuan siswa terhadap kegiatan persemaian dan pengolahan lahan juga dinilai berdasarkan jawaban siswa terhadap 5 pertanyaan pengetahuan dan 5 pertanyaan keterampilan pada kuesioner pada lampiran. Hasil tersebut menunjukkan bahwa persentase pengetahuan yang diperoleh sebesar $93 \%$ tahu dan $95 \%$ terampil terhadap kegiatan persemaian seperti yang ditunjukkan pada Gambar 3, sedangkan pada kegiatan pengolahan lahan berdasarkan hasil survey seperti pada Gambar 4. menghasilkan persentase $92 \%$ tahu dan $95 \%$ terampil dalam pengolahan lahan. Hal ini diartikan bahwa siswa dapat membuat kompos takakura secara mandiri dengan hasil sesuai dengan contoh yang diberikan dan mampu dalam mengaplikasikan penggunaan kompos dalam budidaya tanaman sayuran yang pengaplikasiannya sesuai dengan dosis yang ditentukan.

Hasil tersebut menunjukkan sudah mengalami peningkatan pengetahuan dan keterampilan yang sebelumnya mitra rata-rata masih belum mengetahui teknologi pembuatan kompos setelah adanya pelatihan dan pendampingan siswa dapat mengetahui serta mengaplikasikan pembuatan kompos secara mandiri. Hasil dari praktik mandiri dalam pembuatan kompos dan budidaya tanaman sayuran yang dilakukan siswa mencerminkan peningkatan kesadaran bahwa budidaya tanaman secara organik merupakan salah satu budidaya yang tepat untuk meningkatkan produktivitas tanaman, kesehatan maupun perekonomian. Selain itu menjadikan terbentuknya aktivitas bercocok tanam di lingkungan Pondok Pesantren Miftahul Ulum dengan memanfaatkan lahan tidur yang sudah beberapa waktu tidak termanfaatkan. Secara keseluruhan kegiatan Pemberdayaan Pesantren Miftahul Ulum melalui Budidaya Sayuran Secara Organik dengan Teknologi Takakura dapat dikatakan baik dan berhasil, yang dapat diukur dari aspek pengetahuan dan keterampilan yang meningkat serta kemampuan siswa dalam melakukan secara mandiri.

\section{Pelaksanaan Focus Group Discussion}

Tim Pengabdian Masyarakat Politeknik Negeri Pontianak beserta dengan Yayasan Pondok Pesantren Miftahul Ulum melakukan beberapa kali Focus Group Discussion (FGD) dalam rangka untuk mempersiapkan Tata Kelola Kebun Sayur Organik.

Focus Group Discussion (FGD) 1 (Gambar 6. ) dilaksanakan dengan melibatkan berbagai Pihak mulai dari internal Pondok Pesantren Miftahul Ulum, Tim Pengabdian Masyarakat Politeknik Negeri Pontianak dan juga Pemerintah Desa Sungai Ambangah. Dalam kegiatan ini menghasilkan beberapa poin penting yang salah satunya adalah adanya dukungan penuh dari Pemerintah Desa Sungai Ambangah dalam rangka mendukung kelengkapan administrasi berkaitan dengan pendaftaran kepengurusan Kelompok Pengelola Sayur Organik di Pondok Pesantren.

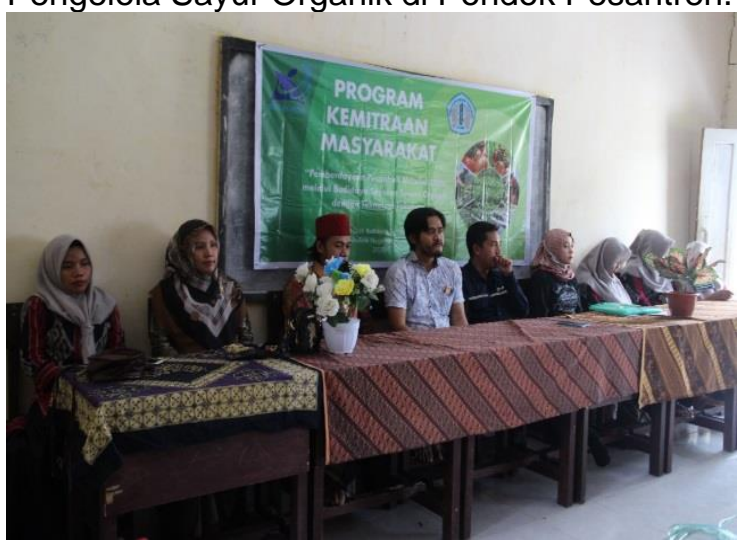

Gambar 6. Focus Group Discussion 1

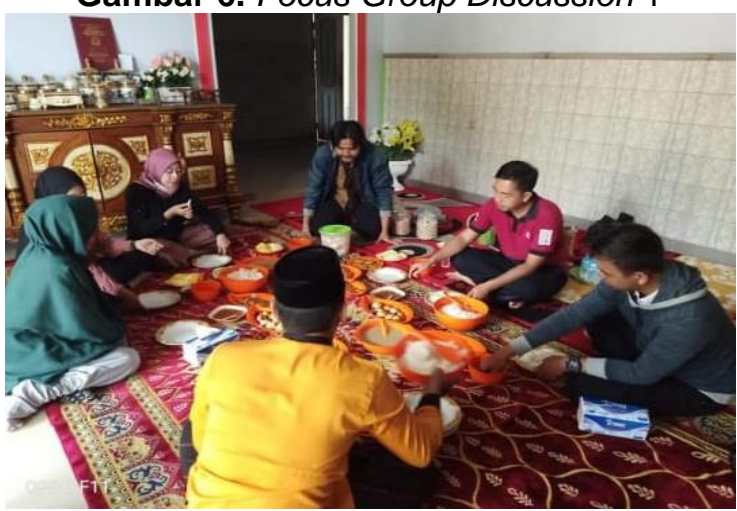

Gambar 7. Focus Group Discussion 2 
Focus Group Discussion (FGD) 2 (Gambar 7.) dilaksanakan dengan melibatkan berbagai Pihak internal Pondok Pesantren Miftahul Ulum dan Tim Pengabdian Masyarakat Politeknik Negeri Pontianak. Kegiatan ini menghasilkan poin-poin penting satu diantaranya adalah tentang bentuk organisasi pengelola kebun sayuran organik di Pondok Pesantren Miftahul Ulum adalah Koperasi dengan nama Koperasi Sayur Organik Miftahul Ulum.

Kegiatan Focus Group Discussion (FGD) di atas juga memberikan dampak yang cukup baik bagi pelaksanaan pengelolaan kebun sayur orgnanik, dimana dalam kegiatan tersebut dapat tergali beberapa hal yang penting bagi keberlangsungan dan keberhasilan pengelolaan kebun.

Setelah kegiatan Focus Group Discussion (FGD) selesai dilaksanakan, kemudian dilakukan survey kepada peserta FGD. Berikut hasil survei stake holder terkait dalam Focus Group Discussion.

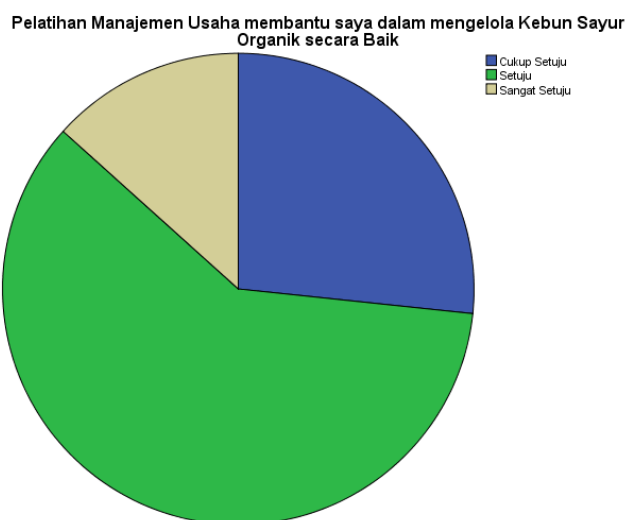

Gambar 8. Tanggapan Responden Terhadap Pelatihan Manajemen

Pada Gambar 8. di atas menunjukkan bahwa mayoritas responden setuju bahwa Pelatihan Manajemen Usaha membantu dalam mengelola usaha kebun sayur organik secara baik.

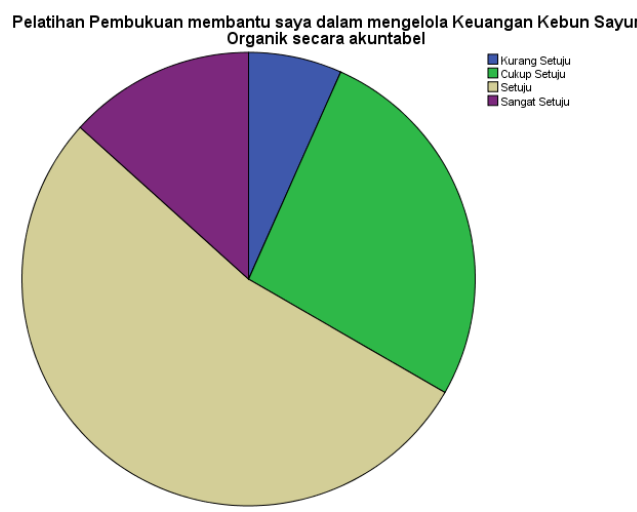

Gambar 9. Tanggapan Responden Terhadap Pelatihan Pembukuan
Pada Gambar 9. menunjukkkan mayoritas responden setuju bahwa pelatihan pembukuan membantu dalam mengelola keuangan Kebun Sayur Organik secara akuntabel.

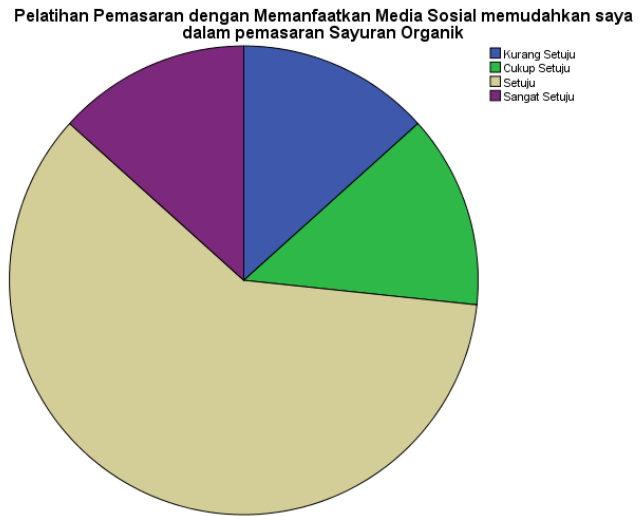

Gambar 10. Tanggapan Responden Terhadap Pelatihan Pemasaran

Gambar 10. menunjukkan bahwa mayoritas responden setuju bahwa pelatihan pemasaran dengan memanfaatkan media social memudahkan dalam pemasaran sayuran organik.

\section{SIMPULAN DAN SARAN Simpulan}

Program pengabdian pemberdayaan pesantren miftahul ulum melalui budidaya sayuran secara organik dengan teknologi takakura dapat diselenggarakan dengan baik dan mendapat sambutan sangat baik. Pengetahuan dan Keterampilan Siswa/siswi Pondok Pesantren Miftahul Ulum meningkat dengan adanya pelatihan dan pendampingan mengenai bercocok tanam tanaman sayuran organik sistem Takakura. Pelatihan manajemen dan pemasaran juga memberikan manfaat positif bagi pihak pesantren.

\section{Saran}

Adanya kegiatan lanjutan yang berupa pelatihan sejenis selalu diselenggarakan secara periodik sehingga dapat meningkatkan kemampuan santri dalam melaksanakan kegiatan bercocok tanam dan pemasaran produk.

\section{UCAPAN TERIMAKASIH}

Penulis menyampaikan ucapan terima kasih kepada Direktorat Riset dan Pengabdian Masyarakat Deputi Bidang Penguatan Riset dan Pengembangan sebagai pemberi dana Pengabdian Kepada Masyarakat ini melalui skema Program Kemitraan Masyarakat Tahun 2019. Ucapan terimakasih juga Penulis sampaikan kepada Politeknik Negeri Pontianak yang sudah memberikan dukungan demi 
terlaksananya Pengabdian Kepada Masyarakat ini.

\section{DAFTAR RUJUKAN}

Manuputty, M. C., Jacob, A., \& Johanis P, J. P. (2018). Pengaruh Effective Inoculant Promi Dan Em4 Terhadap Laju Dekomposisi Dan Kualitas Kompos Dari Sampah Kota Ambon. Agrologia. 1(2):143-51 https://doi.org/10.30598/a.v1i2.290

Nurullita, U., \& Budiyono. (2012). Lama waktu pengomposan sampah rumah tangga berdasarkan jenis mikro organisme lokal (mol) dan teknik pengomposan. Seminar Hasil-Hasil Penelitian - LPPM UNIMUS 2012.

Ratna, D. A. P., Sumiyati, S., \& Samudro, G. (2017). Pengaruh Kadar Air dan Ukuran Bahan terhadap Hasil Pengomposan Sampah Organik TPST Universitas Diponegoro dengan Metode Takakura. Teknik Lingkungan.

Safei, M., Rahmi, A., \& Jannah, D. N. (2014). Pengaruh Jenis dan Dosis Pupuk Organik Terhadap Pertumbuhan Dan Hasil Tanaman Terung (Solanum melongena L.) Varietas Mustang F-1. Jurnal Agrifor Volume XIII : 59-66.

Sudaryono, Wijanarko, A., \& Suyamto. (2015). Efektivitas Kombinasi Amelioran dan Pupuk Kandang dalam Meningkatkan Hasil Kedelai pada Tanah Ultisol. Jurnal Penelitian Pertanian Tanaman Pangan. 30(1):43-51. ttps://doi.org/10.21082/jpptp

Widikusyanto, M. J. (2018). Membuat Kompos Dengan Metode Takakura. Researchgate.Net. 